\title{
MBP wt Allele
}

National Cancer Institute

\section{Source}

National Cancer Institute. MBP wt Allele. NCI Thesaurus. Code C127023.

Human MBP wild-type allele is located in the vicinity of $18 \mathrm{q} 23$ and is approximately $155 \mathrm{~kb}$ in length. This allele, which encodes myelin basic protein, is involved in neuronal development and myelination. 